\title{
Exploration of Practice Teaching of the Agricultural Water Conservancy Engineering major Facing Outstanding Engineer Program
}

\author{
Jin $\mathrm{Jin}^{1,2 * *}$, Dongsheng $\mathrm{Li}^{1 *}$, Gang $\mathrm{Li}^{1}$, Hua Tang ${ }^{1}$ \\ ${ }^{1}$ College of Hydraulic and Constructional Engineering, Shihezi University, Shihezi 832003, Xinjiang, China. *E-mail: \\ dsli909@126.com \\ ${ }^{2}$ National Demonstration Center for Experimental Water Resources and Hydro-electric Engineering Education (Xi' an \\ University of Technology), Xi'an 710048, Shaanxi, China.**E-mail: jinjin@shzu.edu.cn \\ Fund Project: Open project of National Demonstration Center for Experimental Water Resources and Hydro-electric \\ Engineering Education (Xi'an University of Technology) (WRHE1704); Shihezi University Education and Teaching Reform \\ Project(JGH2020-28, GZ-2019-07)
}

Abstract: The "Excellent Engineer Program" is mainly to train application-oriented talents, so it is necessary to build a strong practical teaching system. In order to improve the practical ability of students majoring in Agricultural and Water Conservancy Engineering and strengthen the coordination and cooperation between teaching and practical management, the teaching system should be guided by the needs of the agricultural and water conservancy industry, and build a teaching practice system for outstanding agricultural and water conservancy engineers with "practical teaching as the main body of teaching, and professional ability innovation as the training goal", and gradually improve the students' knowledge of agriculture in understanding and learning, application and innovation of water conservancy projects. Then, it is possible to achieve the goal of training outstanding agricultural and water conservancy engineers. This article explores the Agricultural Water Conservancy Engineering practice teaching for the outstanding engineer program through three aspects: the current teaching status of the Agricultural Water Conservancy Engineering practice, the construction of the Agricultural Water Conservancy Engineering practice teaching system, and the reform measures of the outstanding engineer practice teaching system.

Keywords: Outstanding Engineer; Agricultural Water Conservancy Engineering; Practice

Practical teaching and skill training are both important links to the "Excellent Engineer Program". It plays a special role in cultivating the innovation and practical ability of students majoring in Agriculture Water Conservancy. As a model reform for the cultivation of agricultural and water conservancy engineering talents, the "Excellent Engineer Program" also raises requirements for the practical process of undergraduate teaching. However, the shortcomings of traditional teaching that are not prominent in practical teaching can no longer meet the requirements of the "Excellent Engineer Program". Reforming traditional teaching methods in accordance with the "Excellent Engineer Program" and cultivating outstanding agricultural water conservancy engineers have become an urgent task for colleges and universities. The following article is a brief exploration of the practical teaching of the Agricultural Water Conservancy Engineering major under the Excellent Engineer Program.

\section{The status quo of practical teaching of the Agricultural Water Conservancy Engineering major}

Take Shihezi University as an example. The Agricultural Water Conservancy Engineering major of Shihezi University was

Copyright $\odot 2020$ Jin Jin et al.

doi: $10.18686 /$ ahe.v4i10.2895

This is an open-access article distributed under the terms of the Creative Commons Attribution Non-Commercial License (http://creativecommons. org/licenses/by-nc/4.0/), which permits unrestricted non-commercial use, distribution, and reproduction in any medium, provided the original work is properly cited. 
established in 1960. It has a 60-year history of development. It is also a specialty of Xinjiang's Production and Construction Corps. It is mainly adapted to the needs of the country, especially in border areas. The needs of agricultural and water conservancy projects require the development of all aspects of morality, intelligence, and physical beauty. Students should have professional basic theoretical knowledge of agricultural and water conservancy subjects, basic skills in agricultural and water conservancy projects, good humanities and professional ethics, good communication skills, management skills, and hardworking learning ability. After 60 years of development, this major has outstanding characteristics and advantages in water-saving irrigation in arid areas, planning and design of irrigation areas, and water conservancy improvement and treatment in saline-alkali areas, which enables students with strong professional competitiveness and strong employment adaptability in Xinjiang.

Although Shihezi University has made a lot of improvements in engineering practice and achieved certain results, there are still some problems that need to be solved, mainly in the following aspects: First, the practical ability needs to be further improved, agricultural water conservancy There is a close relationship between major and practice, but from the perspective of long-term teaching methods, it has the disadvantage of focusing on the classroom and neglecting the practice. Most of the professionally arranged experiments are conducted in laboratories, and they are mostly verification experiments. Secondly, the internship has not been implemented yet. There are three comprehensive internships for students' internships, which mainly include the cognitive internship, curriculum internship and production internship. Students are evenly arranged in some companies during the internship stage, but due to factors such as internship funding and student safety when they go out, most students do not fully meet the internship requirements during the internship stage. There is also the problem of poor practical abilities of teachers. According to the requirements of professional certification, the teacher must have practical engineering experience, but as far as the current situation is concerned, the teacher only meets the minimum certification requirements. The teacher's engineering practice ability mainly comes from personally training interns and learning on the spot, so that the practice time is limited.

\section{Construct a practical teaching system for the Agricultural Water Conservancy Engineering major}

Practical teaching is an important part of teaching work, and practical teaching is also the deepening and expansion of theoretical teaching. In the process of constructing the teaching practice system of the Agricultural Water Conservancy Engineering major, the course General Chemistry should be added on the basis of the general teaching experiment, course design and practice, so as to reduce the amount of professional basic engineering and subject basic courses of agricultural water conservancy. It is necessary to increase the practical courses Agricultural Water Conservancy Engineering Drawing to improve the engineering drawing ability of students of this major. According to the needs of the internship unit and the needs of the training objectives, colleges should increase the amount of time for students' practical courses, increase the time for students to participate in practical courses, and enhance the ability of students to understand and solve complex projects.

The practical teaching system can adopt three teaching links, which are mainly: experimental course teaching, concentrated practical teaching and school-enterprise cooperation courses. There are two main types of experiment course teaching, which are the experiment of general education courses and the course experiment of professional education. The course experiment of general education is basic course experiment teaching, which is mainly college physics. The course experiment of professional education includes course experiment of material mechanics, building materials, etc., and the proportion of comprehensive and innovative experiments should be increased in the course experiment, to improve the engineering practice ability of students of the Agricultural Water Conservancy Engineering major. Concentrated practice teaching mainly includes course design, individual experiment and practice.

The undergraduate training goal of the "Excellent Engineer Program" is mainly to cultivate advanced applicationoriented talents who meet the needs of social and economic development and corporate structure adjustment and have good comprehensive qualities, high engineering practice capabilities and innovative capabilities. Therefore, through cooperation between universities and enterprises, two different learning environments are provided for students, and the two jointly build platforms for basic practice, professional practice, and comprehensive job practice. The so-called basic practice platform is mainly built in public practice places in universities. Basic experiments include cognitive experiments, understanding experiments, and verification experiments. It is mainly completed by teachers in colleges and universities under the leadership of students. The platform focuses on cultivating students' agricultural and water conservancy engineering awareness and engineering quality. The professional practice platform is mainly built by professional laboratories and practice bases. Professional experiments include course paper composition, comprehensive experiments, design experiments, innovative 
experiments, and practice processes. The platform mainly cultivates students' engineering practice ability in agricultural water conservancy projects.

\section{Reform measures for the practical teaching system of the Agricultural Water Conservancy Engineering major}

Strengthen the construction of the Agricultural Water Conservancy Engineering major laboratories and practice bases. According to the training objectives of the "Excellent Engineer Program" of the Agricultural Water Conservancy Engineering major, the laboratory should be reformed and constructed from the following points: expanding the opening time of the laboratory and increase investment in professional laboratories, improving the overall utilization rate of the laboratory, introducing professional resources and equipment from cooperative enterprises, and cooperating with enterprises to build laboratories to restore the environment of on-site agricultural water conservancy projects as much as possible. It is also needed to establish a stable on-campus and off-campus practice base for students' learning and provide a good practice environment for agricultural water conservancy projects. Secondly, colleges should optimize the system structure of the Agricultural Water Conservancy Engineering major practice courses. Colleges and universities should actively promote the reform of the teaching content of the Agricultural Water Conservancy Engineering major practice, guided by the combination of learning and engineering practice and the appraisal of professional skills in the Agricultural Water Conservancy Engineering major, to develop cutting-edge technologies to meet the needs of the country and enterprises. It is better to achieve a better connection between curriculum training and work abilities.

In addition, colleges need to strengthen the construction of the "three-level" teaching team. Teachers participating in the Excellent Engineer Program of agricultural and water conservancy projects should have work experience in enterprises in the following ways. Colleges should actively encourage teachers who participate in the Excellent Engineer Program of agricultural water conservancy projects to participate in various professional teacher certification exams. They can take advantage of student internship opportunities and cooperate with corporate instructors. In this case, they can jointly guide students to conduct practical teaching of the Agricultural Water Conservancy Engineering major. Teachers can also take this opportunity to communicate with the company's instructors and exchange experience in teaching and professional knowledge. They should regularly invite senior management or high-level technical personnel from cooperative companies and invite the professionals to give guidance or lectures for the Agricultural Water Conservancy Engineering major. From this, starting from improving the comprehensive strength of teachers, it can realize the construction of a "three-level" teaching team that combines learning and practice with three dimensions of theories, engineering, and skills. It is also demanded to strengthen and improve the cooperation mechanism between the school and the enterprise. The practical teaching of school-enterprise cooperation can be divided into two parts: school learning and enterprise practice. Among them, the learning of professional knowledge in colleges and universities is the basis for the practice of agricultural water conservancy projects in enterprises. The practical learning can effectively enhance students' engineering innovation ability.

\section{Conclusion}

Combined with the Engineering accreditation, the Agricultural Water Conservancy Engineering major fully takes into account the requirements for graduation. The combination of theoretical knowledge teaching and practical teaching plays an active and important role in improving the teaching quality of practical teaching, cultivating outstanding engineers in agricultural and water conservancy engineering, deepening the reform of practical teaching, implementing skills training followed by basic knowledge learning, and integrating practice in the process of theoretical explanation and analysis. It is a teaching method that learns while practicing, and summarizes while participating in work. It will realize good results in comprehensively improving students' practical ability in agricultural water conservancy projects.

\section{References}

1. Chen F, Wang Z, Tang H, et al. Talent training model based on Excellent Engineer Program 2.0. Quality Education in West China 2020; 6(11): 1-2.

2. Wang Y, Liu S, Li B, et al. Research on education and teaching reform of the Agricultural Water Conservancy Engineering major based on engineering education certification. Science Education Journal 2020; (10): 63-64. 